\title{
Virtual factory and relationship marketing - a case study of a Taiwan semiconductor manufacturing company
} Yi-Ching Hsieh ${ }^{\mathrm{a}, *}$, Neng-Pai Lin ${ }^{\mathrm{b}}$, Hung-Chang $\mathrm{Chiu}^{\mathrm{c}}$

${ }^{a}$ Department of Business Administration, Soochow University, 56, Sec.1, Kwei-Yang Street, Taipei, Taiwan, ROC

${ }^{\mathrm{b}}$ Department of Business Administration, National Taiwan University, 50, Lane 144, Sec. 4, Keelung Road, Taipei, Taiwan, ROC

${ }^{\mathrm{c}}$ Department of International Business, Ming Chuan University, 250, Sec.5, Chung-Shan North Road, Taipei, Taiwan, $R O C$

\begin{abstract}
As global competition grows, building and maintaining of long-term customer relations are major concerns of companies, such that relationship marketing becomes a new marketing paradigm. Customer service in addition to manufacturing capability is an important way to keep the customer commitment. The Internet is a powerful information technology used to provide value-added service to customers and to communicate with each other. As such, the Internet-based virtual factory has been proposed to facilitate connections among partners. Taiwan Semiconductor Manufacturing Company (TSMC), one of the world's largest dedicated integrated circuit foundries, constructed its virtual fabrication to strengthen bonds with customers. Customers are able to access directly to TSMC's and its strategic alliance partners' information system and thereby receive immediate status reports of their orders or some other feedback. In this paper, the framework of TSMC's virtual fabrication is introduced, and the competitive advantages resulted from virtual fabrication are investigated. Implications of TSMC's experience are then discussed. (C) 2002 Published by Elsevier Science Ltd.
\end{abstract}

Keywords: Virtual factory; Internet; Electronic commerce; Relationship marketing

\section{Introduction}

In today's business-to-business markets, many companies face intense pressure caused by fast changes in technology, short product life cycle, and fierce global competition. It is increasingly important for companies to help customer's business be able to change production plans as

\footnotetext{
*Corresponding author. Tel.: + 886-2-2311-1531; fax: + 886-2-2507-1311.

E-mail addresses: ychsieh@mail2.scu.edu.tw (Y.-C. Hsieh), nengpai@mba.ntu.edu.tw (N.-P. Lin), chiuhc@ms27.hinet.net (H.-C. Chiu).
} 
market demands dictate. In this situation, much attention has been paid to timely and customized services, which provide customers easy access to and control of the elements throughout the manufacturing process. In the past decade, new thinking about the buyer-seller relationships is so evident that experts have suggested that relationship marketing (RM) is a new marketing paradigm (Webster, 1992; Grönroos, 1994). It focuses on approaches to build, develop and maintain all successful relational exchanges (Berry, 1983; Morgan \& Hunt, 1994; Grönroos, 1994). By building and maintaining customer relationships, the selling partner can achieve higher financial performance (Kalwani \& Narayandas, 1995; Holm, Eriksson, \& Johanson, 1999), customer trust, commitment (Morgan \& Hunt, 1994) and satisfaction (Cannon \& Perreault, 1999). According to resource-based view, Morgan and Hunt (1999) also argued that long-term relationships are one of the sources of sustainable competitive advantage.

To lure new customers and to hold onto existing ones, businesses are investing heavily in information technologies. The Internet plays an ever-increasing role in understanding customer needs, serving customers better, responding faster to customer inquiries, communicating more efficiently with customers and developing new opportunities (Murphy, 1996). It is ultimately appropriate for heightening the dependence of buyer and seller, and managing customer relationship (Angelides, 1997; Armstrong \& Hagel, 1996; Evans \& Wurster, 1997).

The Internet has many potential uses, such as being a source of information, communication tool and distribution channel, depending on the objectives and capabilities of the user (Ranchhod \& Gurãu, 1999). The traditional face-to-face interchange of business marketing gives way to this emerging new transaction tool that helps to standardize and centralize the conversations (Deighton, 1997). According to a survey from Advanced Manufacturing Research, 71\% of manufacturers already use the Internet to communicate with customers, and $11 \%$ plan to do so in the near future (Allnoch, 1997). Despite the perceived importance of the Internet, there are still only limited empirical studies about Internet-enabled relationships (Davis, Buchanan-Oliver, \& Brodie, 1999).

During the past decades, foundries have become one of the fastest growing businesses in the world and the importance and competition in this industry will keep growing in the near future. Foundries have invested in process technology and manufacturing capabilities; however, customer service is the new strategy for foundry companies to differentiate from competitors. The serviceoriented new concept of "virtual fabrication (VF)", which is proposed by the industry, has become one of the critical aspects for achieving competitiveness (Korczynski, 1997). In order to achieve higher levels of customer service, the world's largest integrated circuit (IC) manufacturer, Taiwan Semiconductor Manufacturing Company (TSMC), is constructing its VF. The implementation of VF helps in improving the customer relationships and operational efficiency, and, as a result, brings competitive advantages.

The intention of this paper is, therefore, to contribute to the understanding of the Internet as an enabler that strengthens the relationships between buyers and sellers. More specifically, the purposes of this study are to: (1) introduce the framework of TSMC's VF; (2) explore the influence of important Internet capabilities on customer relationships; and (3) investigate the relationship between the services provided through Internet and operational efficiency improvement.

In the following sections, first we review the past research about the important capabilities of Internet communication and the literature on RM. Next, we describe the case study methodology 
and the VF framework of TSMC. Then, we propose a model of the Internet-enabled VF and the resulting competitive advantages. Finally, we provide some implications and directions for future research.

\section{Literature review}

\subsection{Capabilities of Internet technology}

Cunningham and Tynan (1993) argued that there are two major incentives for developing interorganizational information systems. The more predictable and measurable incentive, or the first-order effect, is efficiency improvement. The less obvious but more important incentive, or the second-order effect, is the impact on buyer-seller relationships and industry structure. In accordance with their classification, the first-order effect of the Internet is to provide opportunities for an organization to become more efficient in managing operations between partners. Beyond these activities, the second-order effect of the Internet is its suitability for communicating and developing customer relationships.

Several empirical studies have been conducted in the past years to explore the influence of Internet capabilities on the ways of doing business. High speed information transfer, high level interactions, elimination of the limitations of time and location, and high levels of flexibility and ubiquity are some important characteristics of the Internet (Berthon et al., 1997). Dutta and Segev (1999) proposed a "Marketspace model", built on two characteristics of Internet communication: interactivity and connectivity, and a business strategy dimension: customer relationships. Sullivan (1999) focused on the functions of corporate home pages, and described two important characteristics of the Internet: information depth and interactivity.

\subsubsection{Interactivity}

The real-time on-line nature of the Internet makes interactions between business and customers more effective and efficient (Dutta \& Segev, 1999). Deighton (1996, 1997) interpreted interactivities as two coexisting abilities. First is addressability. This ability is to address directly an individual but not to broadcast to all who receive the message. Second is responsiveness. When responsiveness exists, the medium can gather and document the response of that individual. These two abilities make possible a third: the ability to take into account each individual's unique response. Interactivity helps in achieving effective communication with customers. Similarly, Sullivan (1999) defined interactivity as the degree to which a dialogue can be generated between the site's owner and their visitors. When customers interact with sellers, they are able to influence the form and content of information exchanged and accelerate economic negotiation (Sullivan, 1999; Peterson, Balasubramanian, \& Bronnerberg, 1997).

A high-interactivity Web site is helpful for collecting customer opinions and complaints. It is also a convenient device for delivering customized products/services based on the understandings coming from long-term interactions (Peppers, Rogers, \& Dorf, 1999; Prakash, 1996). A highly interactive Web site creates a higher termination cost for customers. The more confidential data customers disclose on an interactive Web site and the more they are acquainted with this environment the higher the termination costs. If they change to another service provider, personal 
data and mutual understanding have to be rebuilt, which could decrease their willingness to transfer to another service provider (Ghosh, 1998).

Moreover, a highly interactive Web site helps customers to develop trust toward the service provider. Customers' trust relies on the formation of their expectations about the motives and behaviors of the service provider (Donney \& Cannon, 1997), and repeated interaction enables customers to interpret prior outcomes better, providing a basis for assessing predictability (Doyle \& Roth, 1992; Swan \& Nolan, 1985).

\subsubsection{Connectivity}

Connectivity came from the open and global nature of the Internet. Because of connectivity, corporations are able to provide information to a large size audience. The Internet has become a new mechanism for communication and coordination between corporations and customers or within groups of customers (Dutta \& Segev, 1999). Moreover, Web sites can be connected to one another through hypertext links. A hypertext environment allows for deep and nonlinear searches initiated and controlled by Web users (Hoffman, Novak, \& Chatterjee, 1995). A good design for hypertext links builds content that is intelligible and interesting to users at different levels of understanding (Huizingh, 2000; Maroney, 1997).

Because of the connectivity, the corporation is not constrained by either time or location when providing products or services through the Internet. Given the lack of distance and time constraints, buyers can access information or place orders in much less cost than before.

\subsubsection{Information quality}

High quality information can be provided on the Internet because it is an inexpensive means to search, organize, disseminate and store vast amounts of information (Donthu \& Garcia, 1999; Peterson et al., 1997). It is the basic goal of a Web site to provide information to users (Angehrn, 1997; Huizingh, 2000).

Customer perception of the degree to which a Web site is considered high quality could determine its value to customers (Huizingh, 2000) and affect customers' acceptance of the Web site (Lin \& Lu, 2000). The more the valuable and detailed information provided on the Web site, the higher the breadth of audience categories and user-orientation of the site (Sullivan, 1999), and thus the more likely to gain and retain customers (Honeycutt, Flaherty, \& Benassi, 1998). For the superior capabilities of the Internet, it should be considered an enabler of mutually beneficial relationships with customers that were characterized by interdependence, resources sharing, and cooperation (Angelides, 1997; Richard, 1994; Nath, Akmanligil, Hjelm, Sakaguchi, \& Schultz, 1998).

\subsection{Virtual factory}

There have been some definitions in the literature about virtual enterprise in general and virtual manufacturing or virtual factory in particular. In order to respond quickly to changing market needs, the virtual factory was supposed to be a better and more flexible organization than a traditional monolithic one. Upton and McAfee (1996) defined the virtual factory, "a community of dozens, if not hundreds, of factories, each focused on what it does best, all linked by an 
electronic network that would enable them to operate as one-flexibly and inexpensively regardless their locations". Virtual manufacturing environments can assist a company to rapidly and effectively react to changes in market conditions and technology (McGehee, Hebley, \& Mahaffey, 1994). As one member in the industry network, TSMC defines the VF as the customers' fab. To satisfy many customers, the physical fabrication must provide customized service and mixed products by dynamically changing operation and capacity configuration (Korczynski, 1997). The development or electronic interconnection has dramatically reduced the time and cost of information exchange, effectively linked the processes and allowed the close integration of parties in the value chain (Tang, Shee, \& Tang, 2001).

Previously, the three main interorganizational information technologies that companies have employed are electronic data interchange (EDI), proprietary groupware and dedicated wide-area networks. However, the Internet's open standards and the function of information broker have made it become the most powerful media to integrate partners' operations. Through the Internet, businesses can accommodate a pool of network members whose IT sophistication and relationships vary enormously. Moreover, they can give network members different functionality, including the capability to transfer files, to access data in a central database, and to access and utilize the programs located in distant computers (Upton \& McAfee, 1996). Also, cost consideration is another reason that the traditional IT is being replaced by the Internet.

\subsection{Relationship marketing ( $R M)$}

Transaction cost analysis (TCA), an early work of a Nobel prize winner in Economics, Ronald Coase, is one of the frameworks for analyzing the governance structure between buyers and sellers. It views the governance structure falling on either end of a bipolar continuum: vertical integration or discrete market transactions. Transaction costs are all the costs running the exchange system including developing and maintaining an exchange relationship, monitoring transactional behavior, and guarding against opportunism in a transaction (Pilling, Crosby, \& Jackson, 1994). The basic premise is that when transaction cost is low or absent, economic actors will favor market governance. Otherwise, firms will favor vertical integration (Heide \& Rindfleisch, 1997). RM, however, offers the third option: achieving lower transaction cost through a closer relationship with external suppliers (Heide, 1994; Gummesson, 1996). Researchers discussed the paradigm shift, moving from the traditional adversarial transaction model toward collaborative long-term relationships between sellers and buyers. Upon abandoning the discrete transactional mode, long-term relationship is crafted by formation of mutual trust and expectation of continuity (Heide, 1994). The collaborative approaches seek to lower acquisition and operating costs through joint efforts of the buyer and supplier (Cannon \& Homburg, 2001; Kalwani \& Narayandas, 1995; Noordewier, John, \& Nevin, 1990).

In addition to great product quality, effective and efficient communications are also necessary when building and maintaining long-term customer relationships (Cannon \& Homburg, 2001). For example, Cannon and Perreault (1999) developed taxonomies of six key buyer-seller relationship connectors. Direct linkages between buyer and seller operation systems and mutual information exchange are two key factors for maintaining customer relationships. Evans and 
Wurster (1997) opined that every business is an information business and information defines buyer-seller relationships. When there is a certain communication channel built between organizations and proprietary information owned by each other, there exist customer relationships. Improving the efficiency of communications has become a major concern of companies under the new RM paradigm (Cunningham \& Tynan, 1993).

\section{Case methodology}

The central activity in doing research is to develop and test theory. However, VF is quite a new concept, and more observations are needed before a theory can be developed. Allport (1961) argues that the case study method permits the detailed observations that can reveal various nuances and subtleties of behavior that other empirical methods might miss. Similarly, Eisenhardt (1989) argues that case study research leads researchers to find new theoretical relationships and question old ones.

Case studies are typically used to: (1) describe a heretofore unstudied situation; (2) explore current theory more thoroughly; and (3) support, expand or raise questions about existing theories (McCutcheon \& Meredith, 1993). The purpose of our case study is to explore situations and problems when the VF concept is implemented.

In this study, data was collected by the following steps. First, we gathered information about the background of the firm and how it got started on VF from its homepage (http:// www.tsmc.com.tw/) and other publications. Then, we conducted several in-depth interviews with senior system engineers of TSMC. Each interview lasted about an hour. During the first meeting, the engineers were asked to describe the framework of VF. Questions focused on the pro and cons they have faced thus far and the changes that have occurred since TSMC adopted the VF model were asked in the meetings which followed.

\section{Study profile}

TSMC is one of the world's largest and fastest growing dedicated IC foundry companies. Since founded in 1987, this company has been dedicated to providing manufacturing services for advanced ICs and had a reputation for excellent product quality. It offers a comprehensive set of fabrication processes, including CMOS logic, mixed-mode, volatile and nonvolatile memory and BiCMOS. In 2000, TSMC held a $41 \%$ share of the global foundry market.

Before the 1990s, the vertically integrated companies led the IC industry. In the high capital investment and dynamic environment, however, the risk of running a vertically integrated company has increased dramatically. The industry, therefore, responded to the high risk by disintegration and each company dedicated itself to one or more parts of the processes. Since TSMC was founded, the company has always focused on its core IC foundry business, and has not distracted itself with other pursuits. It, therefore, has been committed to developing advanced manufacturing technology and expanding capacity to keep operating on the leading edge. 
The value chain model proposed by Porter (1985) considered the primary activities that exist in the link from suppliers to customers. The practice of disintegration of IC industry and fierce global competition of foundry fabs have motivated parties in the value chain to emphasize close relationships in addition to process technology and manufacturing excellence. In the value chain of IC industry, customers want to be informed of updated data about their order status, so that they can decide the promise date to their customers and make adjustments when market demand changes. As such, VF was proposed by this industry. In order to differentiate its service quality with competitors, TSMC announced its VF concept and organized a dedicated team to fulfill this concept in 1996. Its strategy was to develop long-term competitive advantages by building and strengthening bonds between TSMC and customers.

\section{The framework of TSMC's VF}

TSMC defines itself as customers' VF. It means that, through interactions with TSMC, customers can have all the benefits of in-house fabrication but without the risks of capital investments. TSMC wants to provide customers real-time information access, increased production flexibility and control of their product requirements. To construct customers' VF, the first step of TSMC was to reengineer itself to become a customer-oriented organization. Then, it chose the appropriate information technology infrastructure for VF. TSMC's VF is composed of three major parts: they are shop floor system, business operations (such as accounting and purchasing processes) and the transmission of real-time information and services to all customers. All these efforts lead to the ultimate goal of customer service.

Before July 1999, customers were able to get access to their order status and technical information through total customer service system (TCS) on the Web. TCS was a Web-based information-sharing tool, which included three parts: total order management (TOM), on-line technical information system (OTIS), and customer service (CS). TOM was the first step toward the realization of VF. With this system, customers were able to make inquiries through WWW directly to TSMC's information system and receive immediate reports about the WIP status and the production and shipping schedules of their orders. In addition, the early warning systems tracked orders and ensured expeditious and accurate deliveries. This system enhanced not only customer control over orders but also TSMC's ability to allocate its capacity efficiently. OTIS was an on-line information system providing customers direct access to technical information that they needed. The two major groups of data content in this system were General Data and Customized Data. General Data included general descriptions about TSMC, technical document of different manufacturing stages, and design manuals and process quality data. Customized Data was the technical reports of each customer's products, including WIP report, test report, and delivery schedule report. The data that customers outside TSMC fabs viewed through the Internet was the same as what employees inside TSMC obtained through their Intranet. CS was a Web-based channel designed for all TSMC's customers to express their experiences and requirements.

In July 1999, TSMC rearranged the subsystems and replaced TCS by a new Web site, TSMCOnline. Together with another two sub-systems, TSMC-Direct and TSMC-Yield Enhancement System (YES), all aspects of communications and procedures are automated and easily accessible, 
thus allowing customers constantly maintaining informed reports on shipments, technology, and inventory.

\subsection{TSMC-Online}

TSMC-Online is a Web-based, browser-accessed information services. It provides customers the real-time visibility of orders, WIP and shipping status during the foundry service cycle. Also, it facilitates customers to place orders, review technical documentation, and place a general query without time or space constraints. The capabilities provided by this system are as follows:

- Review technical documents, brochures, and manuals during foundry selection and chip design stages.

- Submit mask tooling information, enter foundry service request forms, and place orders.

- Check WIP status, weekly schedule reports, lot reports, and daily reports on wafer shipments, backlog, and delivery schedules through the production cycle.

- Review the quality and reliability data, and news or information; such as product yield forecast, R\&D project status, and technical marketing information.

Each TSMC's customer has its own password, and is able to access to these services anytime. For example, a customer planning to use TSMC's 0.18-micron process can download the 0.18 micron technical specification to assist with the chip design. After the product design is complete, the customer can submit mask-tooling information through an online electronic form, can place a production order, and can track the WIP status and shipping schedule (Electronic Buyers' News, 1999). This system makes TSMC's fabs more transparent to customers because they can get all the information in different stages, which lowers the entry barrier for customers. More importantly, TSMC-Online allows customers to change production plans as market demands dictate and to respond to the shortened product life cycles.

\subsection{TSMC-Direct}

Using the Extricity software Inc.'s Alliance as the backbone, TSMC-Direct is a system-tosystem integration service via the Internet and allows customers to participate in off-site manufacturing and achieves business process integration. This software acts as a translator, which receives information from TSMC's engineering systems, product data management systems, manufacturing execution systems, and Enterprise Resource Planning (ERP) applications, and then transforms and stores the information into customers' systems (Electronic Buyers' News, 1998). Thus, the system enables customers to place orders and receive confirmation in real time; track WIP directly; enact collaborative planning and engineering data sharing with TSMC.

This mechanism helps customers to reduce cycle time and production costs. For example, Adeptec Inc., one of TSMC's customers, realized a 50\% improvement in cycle time, and resulted in inventory cost savings by millions of dollars. Also, customers of Adaptec are more satisfied because they can receive products faster than before (Electronic Buyers' News, 1998).

TSMC-Direct also connects TSMC and other supply chain members. For example, TSMC formalized strategic alliance with Advanced Semiconductor Engineering Group (ASE) which is one of the world's largest independent IC packaging companies. With this strategic alliance, 
TSMC can provide customers a faster process flow from wafer fabrication, IC assembly and test services, to direct delivery of packaged parts. In addition, customers are able to "see through" TSMC's VF into the whole virtual processes. (Electronic Buyers' News, 1998). Due to the electronic connection, the business strategy and processes were reengineered and the overall inventory level in the supply chain was reduced.

\subsection{TSMC-YES}

TSMC-YES helps customers to perform engineering analysis in their own sites. This system uses the Internet to establish a direct real-time connection between customers and TSMC's fabs during process development and enables customers' designers and TSMC's engineers to share a common yield-analyzing tool and to obtain a set of real-time test data. The designers can view or analyze test data simultaneously with TSMC's engineers. This shortens process development cycle time, simulates a customer-owned fab, and improves product yields. TSMC-YES also maintains complete histories that correlate the yield of every lot with its process history. Using this system, customers can work with TSMC to quickly identify major yield limitations while ramping up a new product introduction.

Before the implementation of TSMC-YES, customers had to download raw data into spreadsheets when performing in-depth engineering analysis. It delayed the feedback to TSMC. With TSMC-YES, data travels from the TSMC foundry over the Internet directly to the customer site. The customer then gains access to the data and responses promptly, resulting in more accurate and efficient analysis and troubleshooting.

The hierarchy of TSMC's VF is illustrated in Fig. 1. The information transmission between TSMC and customers is primarily through the Internet, and all the data will be collected in a centralized data warehouse.

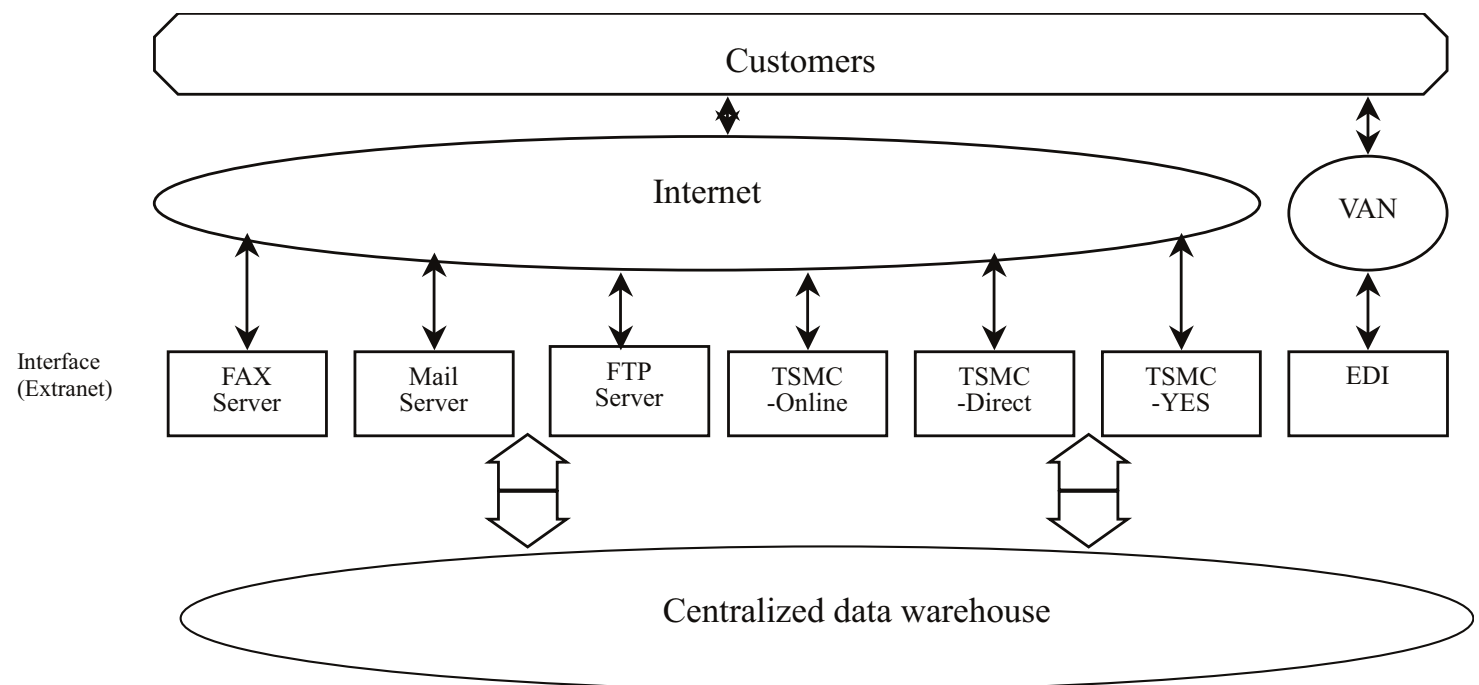

Fig. 1. The hierarchy of TSMC's VF. 
Table 1

Business processes of TSMC

\begin{tabular}{|c|c|c|c|c|}
\hline $\begin{array}{l}\text { Value chain } \\
\text { activities }\end{array}$ & Design & Production & $\begin{array}{l}\text { Engineering } \\
\text { analysis }\end{array}$ & Customer service \\
\hline \multirow[t]{3}{*}{ Business processes } & Design rule & $\begin{array}{l}\text { Order placement, } \\
\text { WIP, shipping } \\
\text { notice }\end{array}$ & Engineering data & $\begin{array}{l}\text { Customer } \\
\text { feedback }\end{array}$ \\
\hline & $\begin{array}{l}\text { Process control } \\
\text { monitor } \\
\text { specification }\end{array}$ & $\begin{array}{l}\text { Shipping reports, } \\
\text { backlog reports }\end{array}$ & Analysis tool & Problem solving \\
\hline & Process flow & $\begin{array}{l}\text { Testing program } \\
\text { and quality } \\
\text { inspection data }\end{array}$ & & \\
\hline Solutions & $\begin{array}{l}\text { Provide on-line } \\
\text { documents to } \\
\text { facilitate } \\
\text { customers' } \\
\text { product design. }\end{array}$ & $\begin{array}{l}\text { Reduce product } \\
\text { cycle time, and } \\
\text { provide customers } \\
\text { full visibility of } \\
\text { product status. }\end{array}$ & $\begin{array}{l}\text { Customers can } \\
\text { perform on-line } \\
\text { yield analysis at } \\
\text { their own sites, } \\
\text { using the same } \\
\text { data, tool and } \\
\text { model with } \\
\text { TSMC's } \\
\text { engineers. }\end{array}$ & $\begin{array}{l}\text { On-line system-to- } \\
\text { track post-sale } \\
\text { events and } \\
\text { problem solving } \\
\text { status. }\end{array}$ \\
\hline $\begin{array}{l}\text { Communication } \\
\text { technologies }\end{array}$ & WWW & $\begin{array}{l}\text { FTP, EDI, } \\
\text { WWW, system-to- } \\
\text { system integration } \\
\text { software (alliance) }\end{array}$ & $\begin{array}{l}\text { WWW, system-to- } \\
\text { system integration } \\
\text { software (alliance) }\end{array}$ & WWW \\
\hline
\end{tabular}

TSMC's VF provides solutions to meet customers' various needs at each value chain stage. Different IT infrastructure is employed to share data with customers (see Table 1).

\section{The competitive advantages from the implementation of VF}

From the experiences of TSMC, we can see some competitive advantages from the implementation of VF (Fig. 2). Competitive advantage can be seen as a result from the implementation of a strategy which is not implemented currently by competitors or from better implementation of the same strategy as competitors, and can be expected to lead to superior marketplace performance and financial performance (Bharadwaj, Varadarajan, \& Fahy, 1993). The following paragraphs are some propositions and analyses from the viewpoint of TCA and RM.

\subsection{Virtual factory and customer relationships}

Berry (1995) suggested three types of bonds that companies can use to foster customer relationships: financial bond, social bond and structural bond. Financial and social bonds focus 


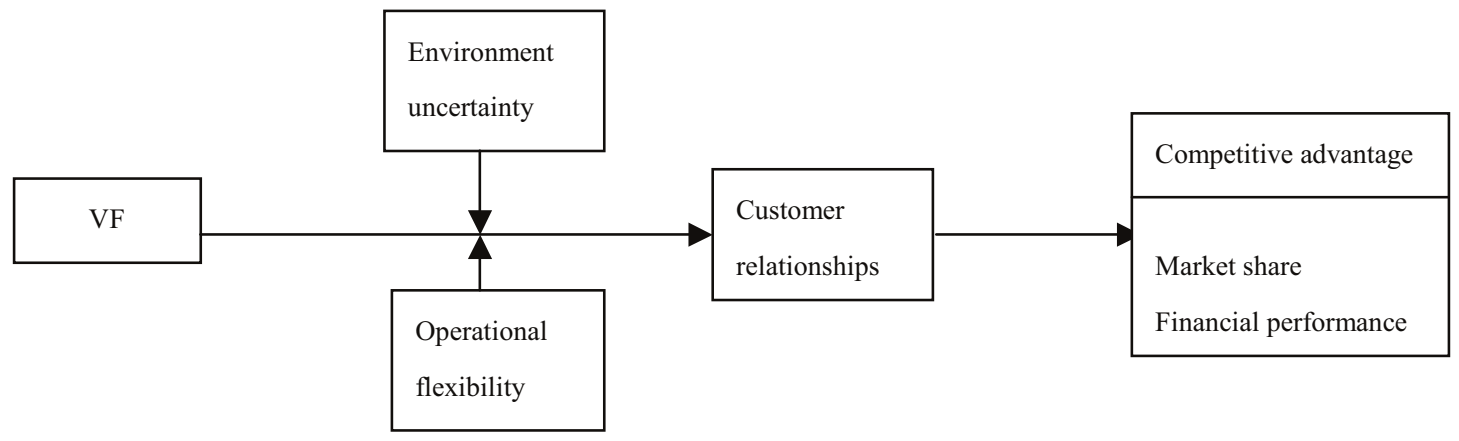

Fig. 2. Conceptual model of the competitive advantage of VF.

on pricing incentives and on personalization of relationships, respectively; and the structural bond builds customers' requirements into the value-delivery system. With VF, TSMC's customers receive value-added services directly through the Internet. Because of the connectivity of the Internet, customers can keep in touch with TSMC or its strategic alliance partners at any time and any place, which is a structural bond between customers and suppliers. It provides customers value-adding benefits that is difficult for competitors to imitate, and helps to maintain long-term relationships with customers (Berry, 1995).

Similarly, Cannon and Perreault (1999) specify six highly independent connectors that characterize the relationships between buyers and sellers. Operational linkage is one of the connectors which is defined as the degree to which the systems, procedures and routines of buyers and sellers have been linked to facilitate the flow of goods, services and information. The IMP group considers a similar concept "technical bonds", which emphasizes the interconnected technical or production processes (Johanson \& Mattson, 1987). TSMC builds the operational connections with customers by its VF. All aspects of communications and procedures are automated and easily accessible to the customers, keeping them constantly informed and up-todate on shipments, technology, inventory, etc. By facilitating exchange and reducing transaction costs, it may create dependence and switching cost for customers (Stern \& Reve, 1980), and strengthen the relationships.

Besides, RM techniques have placed a great emphasis on information and communication. In service selling, mutual disclosure has been positively linked to customer trust and satisfaction (Crosby, Evans, \& Cowles, 1990). Communication frequency (Mohr, Fisher, \& Nevin, 1996) and open information sharing (Heide \& John, 1992) are essential in buyer-seller relationships. The communication efficiency of the Internet is important especially for companies whose value-added contribution is concentrated in the information side of their products, such as high-tech companies (Benjamin \& Wigand, 1995; Watson \& Zinkhan, 1997; Ranchhod \& Gurãu, 1999).

From transaction cost considerations, buyers might prefer the suppliers who provide VF arrangements. Through VF, customers are able to track order status and shipping schedules without time and distance constraints, and their acquisition costs are minimized because the connectivity enhances the efficiency of client booking procedures and monitoring efforts (Cannon \& Homburg, 2001). In addition, VF provides customers the manuals and documents for fabrication selection and product design, and engineers transmit CAD drawings among customers 
via the Internet instead of sending them by fax. These real-time interactions and rich information transmission reduced customers' operation costs, including research and development and manufacturing (Cannon \& Homburg, 2001; O'Neal, 1993). Based on the above discussion, we propose:

Proposition 1. The implementation of VF helps strengthen the relationships between customer and suppliers.

\subsection{Sustainable competitive advantage}

Barney (1991) listed four requirements to qualify a skill for a source of sustainable competitive advantage, it should be valuable, rare, imperfect imitable with no strategically equivalent substitutes. Coyne (1985) pointed out that even the competitors own the same resource as yours, it can still be a source of sustainable competitive advantage if there is a capability gap making difference to customers. The sustainable competitive advantage will lead to superior market and financial performance (Bharadwaj et al., 1993).

Morgan and Hunt (1999) clarified the kinds of resources that might be gained through relationships. In TSMC's case, it might obtain "relational resources" and "informational resources" according to Morgan and Hunt's discussion. TSMC's customer-oriented philosophy and VF's customer service capability help to develop customer trust and commitment, which are intangible and advantage-sustaining relational resources for TSMC (Dierickx \& Cool, 1989; Day $\&$ Wensley, 1988). Besides, the VF is a system to gather, disseminate and apply information and is able to perpetuate the possession, the valuable customer information. It helps to accumulate the inventory of informational resources and build its ability to learn (Morgan \& Hunt, 1999).

Provided mutual communications and production flexibility, customers' acquisition costs and operations costs shall be reduced and their intention to expand future purchases shall increase (Cannon \& Homburg, 2001). As a result, supplier's market and financial performance could improve. Based on the above discussion, we propose:

Proposition 2. Building customer relationships through VF is a source of sustainable competitive advantage, and it results in higher market and financial performance.

\subsection{Environmental uncertainty}

In TCA, environmental uncertainty, reflecting in the rate of technological change, the complexity of the environment and the number of factors to be projected into the future, is one of the major antecedents of transaction cost (Pilling et al., 1994). The unpredictable environment coupled with the bounded rationality further increase the difficulty to write a complete contingent contract (Rindfleisch \& Heide, 1997). As a result, unanticipated circumstances in a dynamic environment give firms an incentive to create negotiated environments. If unforeseeable changes did happen, deliberately designed-in incompleteness permits coordination and beneficial revisions within such an environment (Buvik \& John, 2000). Relational ties or vertical coordination, the 
purposive organization of activities and information flows between independent firms, is an effort to reduce the problems of product design changes, production planning, and so on (Buvik \& John, 2000, Dowst, 1988; Drozdowski, 1986; Frazier, Spekman, \& O’Neal 1988; Spekman, 1988). Noordewier et al. (1990) showed that relational ties improve purchasing performance when uncertainty is high. Pilling et al. (1994) also concluded that information flows were more valuable when environmental uncertainty increased transaction costs.

In the IC industry, the ability to monitor and manage shopfloor processes in real time often determines a company's profitability. For TSMC's customers, it is important to make production decisions to respond to changing market demand. During wafer manufacturing, however, there are a number of processes that determines what the wafer will become and how it eventually will be used. Once the wafer passes the point of no return, then it is impossible to fill a different order. It is helpful to provide these customers a Web site to monitor production status, and they have the chances to hold or change orders (Fulcher, 1999).

VF collects customer requirements from Web pages and responds them as quickly as possible. The real-time interactions in designing, producing and testing stages have shortened the time to market and have improved product quality. Furthermore, the primary goal of TSMC's VF is to offer the control and flexibility benefits of vertical integration to those fabless customers. The connections by the Internet among TSMC, its strategic alliance partners and customers facilitate the reconfiguration of the organizations to respond quickly to changing market needs. The interactivity and information-rich characteristics of the Internet permits better coordination and management of business operations between partners who take on responsibility for one or more functions of the value-adding processes. (Poon \& Jevons, 1997) and helps lessen the influence of environmental uncertainty and lower transaction costs (Pant \& Hsu, 1996).

According to its ability, VF is more helpful to customers who face a dynamic market. In other words, it is more beneficial in an uncertain environment for the efforts on transaction costs are more pronounced under high environmental uncertainty (Buvik \& John, 2000). Compared to a static environment, customers can perceive the higher levels of service improvement and transaction costs reduction provided by VF in a dynamic environment. Based on the above discussion, we propose:

Proposition 3. The greater the uncertainty of the environment facing the industry, the greater the relationship between VF and customer relationships.

\subsection{Operational flexibility}

In a relatively stable world, the traditional practice in manufacturing rely more on standardized, long-life and low information-content products (Gunasekaran, 1998). To avoid the production cost and quality being harmed, manufacturers often drew a boundary between the internal system and external environment to protect their "technical core" (Bowen \& Jones, 1986). Without customers' intervention, producers can make production plans according to forecasts.

However, the increasing global competition demands the companies now not only be able to predict variations but also be able to change with these uncertain environments (Sharp, Irani, \& 
Desai, 1999). Current focus of manufacturing lies on customized, short market-life, ad high information-content products (Gunasekaran, 1998). The open-system viewpoint has led to the management philosophy of adaptation. Lawrence and Dyer (1983) defined the concept of adaptation as the "process by which organization and its environment reach and maintain an equilibrium ensuring the survival of the system as a whole".

In operations management research, operational flexibility is a solution for adaptation problems (Gerwin, 1993; Mandelbaum, 1978; Slack, 1983, 1987; Swamidass \& Newell, 1987; Upton, 1995; Zelenovic, 1982). Operational flexibility is a multidimensional construct, and many different types of flexibility have been proposed by the past research. For example, product customization flexibility and volume flexibility are two types of flexibility. Product customization flexibility is the ability to accommodate each customer's unique requirements. Volume flexibility is the ability to quickly increase or decrease the quantity of output to handle fluctuations in market demand (Krajewski \& Ritzman, 1992). VF is an environment open to customers to make requirements and order adjustments. Operational flexibility is therefore very important for suppliers to fulfill the VF concept. An organization without the operational flexibility to deal with uncertainties caused by customer intervention will be harmed by higher costs and lower product quality. Moreover, lacking of operational flexibility to fulfill the promises, suppliers could hardly be able to build and maintain customer relationships (Grönroos, 1994). Based on the above discussion, we propose:

Proposition 4. The greater the operational flexibility, the greater the relationship between VF and customer relationships.

\section{Conclusions}

Over the past few years, TSMC has become one of the world's largest and fastest growing dedicated IC foundry companies. This article, has attempted to describe the contents of TSMC's $\mathrm{VF}$, which is one of the important factors that leads to success. After the implementation of the VF of TSMC, customers can have all the benefits of in-house fabrication without the risks of capital investments. For example, customers can track their orders and make requirements through the Internet on real time to meet their specific needs. Moreover, customers can get all information in different stages such as product design, order placement, wafer production, yield analysis, and test and assembly, which lowers the entry barrier and transaction cost for its customers.

Virtual fabrication is quite a new concept. It could be helpful to understand the different aspects of implementation of virtual fabrication by viewing a particular case in depth. While this methodology has its limitation in generalization findings across business settings, the insights gained could be of value to some different business situations. Much more knowledge may hopefully be added to this subject through accumulating study of case examples.

From the experience of TSMC, VF tends to increase the possibility of building exchange relationships and helps strengthen the bonds with customers. Under the uncertain environment, VF is more likely to be a source of competitive advantages, and at the same time, leads to longterm customer relationships. Operational flexibility, however, could moderate the relationship 
between VF implementation and customer relationships. Furthermore, stable customer relationships could result in higher market and financial performance. Future research could examine the above propositions through empirical data.

Some managerial factors may lead to successful VF. In the case of TSMC, knowledge management practice and customer orientation philosophy may be two key successful factors. Knowledge management is the process of capturing a company's collective expertise (Hibbard, 1997) and an attempt to contain the massive amount of information, organize it logically, and make it accessible to the right people, on time (Ginhereau, 1997). The company which invests in knowledge management projects records, sorts, and stores its experience effectively and forms a historical database. From this database its employees draw and analyze information on customer preferences and activities. In TSMC, knowledge management is an important focus in addition to the traditional managerial concerns. Employees in TSMC always learn the newest knowledge from books or from discussions with colleagues. Therefore, the speed of knowledge creation and diffusion is very high. Also, all the knowledge is well sorted, standardized and filed, which allows the knowledge to be diffused widely and preserved for long time. Although the construction of VF is not an easy task, TSMC fulfilled this goal gradually by applying all the knowledge accumulated through time. The relationship between knowledge management and customer relationship building could be another research topic.

Another important business philosophy of TSMC is treating customers as partners. It never designs or manufactures its own brandname IC end products to compete against customers but, on the contrary, values customer successes and abilities as its own. As such, constructing a system that is helpful to customer success and to achieve customer satisfaction is the most important goal in TSMC. Moreover, TSMC's Web site offers an efficient communication tool for customers to express their complaints or requirements. All feedbacks are reviewed by customer engineers and are stored in their database. Therefore, TSMC is able to revise VF according to customer opinions. How the management philosophy influences the success of VF implementation and customer relations is also worth researching in the future.

\section{References}

Allnoch, A. (1997). Manufacturers embrace Internet as customer service tool. IIE Solutions, $29(8), 8$.

Allport, G. W. (1961). Patterns in growth and personality. New York: Holt, Rinehart and Winston.

Angehrn, A. (1997). Designing mature Internet strategies: The ICDT model. European Management Journal, 15(4), 361-369.

Angelides, M. C. (1997). Implementing the Internet for business: A global marketing opportunity. International Journal of Information Management, 17(6), 405-419.

Armstrong, A., \& Hagel III, J. (1996). The real value of on-line communities. Harvard Business Review, 74(3), 134-141.

Barney, J. B. (1991). Firm resources and sustainable competitive advantage. Journal of Management, 17, 99-120.

Benjamin, R., \& Wigand, R. (1995). Electronic markets and virtual value chains on the information superhighway. Sloan Management Review, 36(2), 62-72.

Berthon, P., Pitt, L., Berthon, J. P., Crowther, C., Bruwer, L., Lyall, P., \& Money, A. (1997). Mapping the marketspace: Evaluating industry Web sites using correspondence analysis. Journal of Strategic Marketing, 5(4), $233-242$.

Berry, L. L. (1983). Relationship marketing. In L. Berry, G. L. Shostack, \& G. D. Upah (Eds.), Emerging perspectives on services marketing (pp. 25-28). Chicago: American Marketing Association. 
Berry, L. L. (1995). Relationship marketing of services: Growing interest, emerging perspectives. Journal of the Academy of Marketing Science, 23(4), 236-245.

Bharadwaj, S. G., Varadarajan, P. R., \& Fahy, J. (1993). Sustainable competitive advantage in service industries: A conceptual model and reseach propositions. Journal of Marketing, 57, 83-99.

Bowen, D. E., \& Jones, G. R. (1986). Transaction cost analysis of service organization-customer exchange. Academy of Management Review, 11(2), 428-441.

Buvik, A., \& John, G. (2000). When does vertical coordination improve industrial purchasing relationships? Journal of Marketing, 64, 52-64.

Cannon, J. P., \& Homburg, C. (2001). Buyer-seller relationships and customer firm costs. Journal of Marketing, 65, 29-43.

Cannon, J. P., \& Perreault Jr., W. D. (1999). Buyer-seller relationships in business markets. Journal of Marketing Research, 36, 439-460.

Coyne, K. P. (1985). Sustainable competitive advantage — what it is, what it isn't. Business Horizons, 29, 54-61.

Crosby, L. A., Evans, K. R., \& Cowles, D. (1990). Relationship quality in service selling: An interpersonal influence perspective. Journal of Marketing, 54, 68-81.

Cunningham, C., \& Tynan, C. (1993). Electronic trading, inter-organizational systems and the nature of buyer-seller relationships: The need for a network perspective. International Journal of Information Management, 13, 3-28.

Davis, R., Buchanan-Oliver, M., \& Brodie, R. (1999). Relationship marketing in electronic commerce environments. Journal of Information Technology, 14, 319-331.

Day, G. S., \& Wensley, R. (1988). Assessing advantage: A framework for diagnosing competitive superiority. Journal of Marketing, 52, 1-20.

Deighton, J. (1996). The future of interactive marketing. Harvard Business Review, 74(6), 151-161.

Deighton, J. (1997). Commentary on 'Exploring the implications of the Internet for consumer marketing'. Journal of the Academy of Marketing Science, 25(4), 347-351.

Dierickx, I., \& Cool, K. (1989). Asset stock accumulation and sustainability of competitive advantage. Management Science, 12, 1011-1504.

Donney, P. M., \& Cannon, J. P. (1997). An examination of the nature of trust in buyer-seller relationships. Journal of Marketing, 61(2), 35-51.

Donthu, N., \& Garcia, A. (1999). The Internet shopper. Journal of Advertising Research, 39(3), 52-58.

Dowst, S. (1988). Quality suppliers: The search goes on. Purchasing, 94A, 4-12.

Doyle, S. X., \& Roth, G. T. (1992). Selling and sales management in action: The use of insight coaching to improve relationship selling. Journal of Personal Selling and Sales Management, 12, 59-64.

Drozdowski, T. E. (1986). At BOC they start with the product. Purchasing, 62 B, 5-11.

Dutta, S., \& Segev, A. (1999). Business transformation on the Internet. European Management Journal, 17(5), 466-476.

Eisenhardt, K. M. (1989). Building theories from case study research. Academy of Management Review, 14, 532-550.

Evans, P.B., \& Wurster, T. S. (1997). Strategy and the new economics of information. Harvard Business Review, 75(5), $70-82$.

Frazier, G. L., Spekman, R. E., \& O’Neal, C. R. (1988). Just-in-time exchange relationships in industrial markets. Journal of Marketing, 52, 52-67.

Fulcher, J. (1999). Next best thing to being there. Manufacturing System, 17(10), 60-64.

Gerwin, D. (1993). Manufacturing flexibility: A strategic perspective. Management Science, 39(4), 395-410.

Ghosh, S. (1998). Making business sense of the Internet. Harvard Business Review, 93-109.

Ginhereau, B. (1997). Knowledge equals power. InfoWorld, 19(46), 116-123.

Grönroos, C. (1994). From marketing mix to relationship marketing: Towards a paradigm shift in marketing. AsiaAustralia Marketing Journal, 2, 9-29.

Gummesson, E. (1996). Relationship marketing and imaginary organizations: A synthesis. European Journal of Marketing, 30(2), 31-44.

Gunasekaran, A. (1998). Agile manufacturing: Enablers and an implementation framework. International Journal of Production Research, 36(5), 1223-1247.

Heide, J. B. (1994). Interorganizational governance in marketing channels. Journal of Marketing, 58, 71-85.

Heide, J. B., \& John, G. (1992). Do norms matter in marketing relationships? Journal of Marketing, 56, 32-44. 
Hibbard, J. (1997). Knowing what we know. Information Week, 653, 46-64.

Hoffman, D.L., Novak, T.P., \& Chatterjee, P. (1995). Commercial scenarios for the Web: Opportunities and challenges. Journal of Computer-mediated Communication, special issue on Electronic Commerce, 1 (December). [http:// shum.huji.ac.iU jcme/vol 1/issue3/vol 1 no3.htm1]

Holm, D. B., Ericcson, K., \& Johanson, J. (1999). Creative value through mutual commitment to business network relationships. Strategic Management Journal, 20, 467-486.

Honeycutt, E. D., Flaherty, T. B., \& Benassi, K. (1998). Marketing industrial products on the Internet. Industrial Marketing Management, 27, 63-72.

Huizingh, E. K. R. E. (2000). The content and design of Web sites: An empirical study. Information and Management, $37,123-134$.

Johanson, J., \& Mattson, L. (1987). Interorganizational relations in industrial systems: A network approach compared with the transaction-cost approach. International Studies of Management and Organization, 17, $34-48$.

Kalwani, M. U., \& Narayandas, N. (1995). Long-term manufacturer-supplier relationships: Do they pay off for supplier firms? Journal of Marketing, 59, 1-16.

Korczynski, E. (1997). ERSO's children grow up. Solid State Technology, 40(2), s14-s15, s23-s24.

Krajewski, L. J., \& Ritzman, L. P. (1992). Operations management (3rd ed). Reading, MA: Addison-Wesley.

Lawrence, P. R., \& Dyer, P. (1983). Renewing American industry. New York: The Free Press.

Lin, J. C. -C., \& Lu, H. -P. (2000). Towards an understanding of the behavioural intention to use a Web site. International Journal of Information Management, 20(3), 197-208.

Mandelbaum, M. (1978). Flexibility in decision making: An exploration and unification. Ph.D. Thesis, Department of Industrial Engineering, University of Toronto, Canada.

Maroney, D. (1997). In praise of hypertext. Journal of Advertising Research, 37(2), 7-9.

McCutcheon, D. M., \& Meredith, J. R. (1993). Conducting case study research in operations management. Journal of Operations Management, 11, 239-256.

McGehee, J., Hebley, J., \& Mahaffey, J. (1994). The MMST computer-integrated manufacturing system framework. IEEE Transactions on Semiconductor Manufacturing, 7(2), 107-116.

Mohr, J., Fisher, R. J., \& Nevin, J. R. (1996). Collaborative communication in interfirm relationships: Moderating effects of integration and control. Journal of Marketing, 60, 103-115.

Morgan, R. M., \& Hunt, S. D. (1994). The commitment-trust theory of relationship marketing. Journal of Marketing, $58,20-38$.

Morgan, R. M., \& Hunt, S. D. (1999). Relationship-based competitive advantage: The role of relationship marketing in marketing strategy. Journal of Business Research, 46, 281-290.

Murphy, D. (1996). Fishing by the Net. Marketing, August 22, 25-27.

Nath, R., Akmanligil, M., Hjelm, K., Sakaguchi, T., \& Schultz, M. (1998). Electronic commerce and the Internet: Issues, problems, and perspectives. International Journal of Information Management, 18(2), 91-101.

Noordewier, T. G., John, G., \& Nevin, J. R. (1990). Performance outcomes of purchasing arrangements in industrial buyer-vendor relationships. Journal of Marketing, 54, 80-93.

O'Neal, C. (1993). Concurrent engineering with early supplier involvement: A cross-functional challenge. International Journal of Purchasing and Materials Management, 29, 3-9.

Pant, S., \& Hsu, C. (1996). Business on the Web: Strategies and economics. Computer Networks and ISDN Systems, 28(7-11), 1481-1492.

Peterson, R. A., Balasubramanian, S., \& Bronnenberg, B. J. (1997). Exploring the implications of the Internet for consumer marketing. Journal of the Academy of Marketing Science, 25(4), 329-346.

Peppers, D., Rogers, M., \& Dorf, B. (1999). IS your company ready for one-to-one marketing? Harvard Business Review, 77(1), 151-158.

Pilling, B. K., Crosby, L. A., \& Jackson Jr., D. W. (1994). Relational bond on industrial exchange: An experimental test of the transaction cost economic framework. Journal of Business Research, 30, 237-251.

Poon, S., \& Jevons, C. (1997). Internet-enabled international marketing: A small business network perspective. Journal of Marketing Management, 13, 29-41.

Porter, M. E. (1985). Competitive advantage: Creating and sustaining superior performance. New York: The Free Press. 
Prakash, A. (1996). The Internet as a Global Strategic IS Tool. Information Systems Management, 13(3), 45-49.

Ranchhod, A., \& Gurãu, C. (1999). Internet-enabled distribution strategies. Journal of Information Technology, 14, 333-346.

Richard, C. (1994). Internet: The missing marketing medium found. Direct Marketing, 57, 20-23.

Rindfleisch, A., \& Heide, J. B. (1997). Transaction Cost Analysis: Past, Present, and Future Applications. Journal of Marketing, 61(4), 30-54.

Sharp, J. M., Irani, Z., \& Desai, S. (1999). Working towards agile manufacturing in the UK industry. International Journal of Production Economics, 62(1-2), 155-169.

Slack, N. (1983). Flexibility as a manufacturing objective. International Journal of Operation and Production Management, 3(3), 4-13.

Slack, N. (1987). The flexibility of manufacturing systems. International Journal of Operation and Production Management, 7(4), 35-45.

Spekman, R. E. (1988). Strategic supplier selection: Understanding long-term buyer relationships. Business Horizons, $31,75-81$.

Stern, L. W., \& Reve, T. (1980). Distribution channels as political economies: A framework for comparative analysis. Journal of Markeitng, 44, 52-64.

Sullivan, J. (1999). What are the functions of corporate home pages? Journal of World Business, 34(2), 193-210.

Swamidass, P. M., \& Newell, W. T. (1987). Manufacturing strategy, environmental uncertainty and performance: A path analytical model. Management Science, 32(4), 509-524.

Swan, J. E., \& Nolan, J. J. (1985). Gaining customer trust: A conceptual guide for the salesperson. Journal of Personal Selling and Sales Management, 5(2), 39-48.

Tang, J. E., Shee, D. Y., \& Tang, T.-I. (2001). A conceptual model for interactive buyer-seller relationship in electronic commerce. International Journal of Information management, 21, 49-68.

Upton, D. M. (1995). What really makes factories flexible? Harvard Business Review, 73(4), 74-81.

Upton, D.M., \& McAfee, A. (1996). The real virtual factory. Harvard Business Review, 74(4), 123-133.

Watson, R. T., \& Zinkhan, G. M. (1997). Electronic commerce strategy: Addressing the key questions. Journal of Strategic Marketing, 5, 189-209.

Webster, F. E. (1992). The changing role of marketing in the corporation. Journal of Marketing, 56, 1-17.

Zelenovic, D. M. (1982). Flexibility: A condition for effective production systems. International Journal of Production Research, 20(3), 319-337.

Yi-Ching Hsieh is an Assistant Professor of Business Administration at Soochow University, Taiwan. Her research interests include relationship marketing and Internet marketing.

Neng-Pai Lin is a Professor of Management at National Taiwan University, Taiwan. He is also a minister of state and chairman of Public Construction Commission, Executive Yuan of Republic of China. He received his Ph.D. in Management from Ohio State University (1989). His research interests include technology management, strategy, quality and operations management.

Hung-Chang Chiu is an Assistant Professor of International Business at Ming Chuan University, Taiwan. His research interests are services marketing and Internet marketing. 